\title{
Model and Practice of Strategic Policy Process in Indonesia: Case Study Strategic Management in Indonesian Central Government (2009-2012)
}

\author{
Achmad Nurmandi \\ Department of Government Affairs and Administration \\ Chairman of Jusuf Kalla School of Government, Universitas Muhammadiyah Yogyakarta, Yogyakarta, Indonesia \\ Tel: 62-27-438-7656_E-mail: nurmandi_achmad@ymail.com, nurmandi_achmad@umy.ac.id \\ Received: July 3, 2012 \\ Accepted: July 28, 2012 \\ Online Published: October 31, 2012 \\ doi:10.5430/jms.v3n4p65 \\ URL: http://dx.doi.org/10.5430/jms.v3n4p65
}

\begin{abstract}
Since 1998, the Indonesian government had introduced an approach for Strategic Management under Government Regulation No. 108/200 the government has not evaluated experiences with this strategy. However, in 2009, the administration of President Yudhoyono introduced a new approach entitled Rencana Pembangunan Jangka Menengah (RPJMD) -Medium Term Development Planning. The interesting question regards the compliance of government with this strategic plan. In other words, is the implementation of the strategic plan proceeding? In this paper, both writers investigate experiences with the attempt to introduce the model and practice of Strategic Management in the Indonesian public sector, particularly the aspects of process and tools. The Research method used in this research is historical and descriptive using the casual loop model of system dynamics method. The study found that the model of strategic planning applied by the government was a linear process model a linked to key success factors of leadership, professional coordination among governmental units, and monitoring of the complete process and its instruments: planning, implementation and evaluation.
\end{abstract}

Keywords: Policy, Strategic management, Strategic plan, Public sector

\section{Introduction}

Since entering democratic political practice in 1998, Indonesia has deals with some constraints especially in government effectiveness. Democracy requires inefficient consultation and decision making processes and it therefore must involve the nine factions in the House of Representatives which have different concerns. In the previous term, the ex-president, Soeharto, had a strategic plan document known as Garis-garis Besar Haluan Negara (GBHN) - Guidelines of State Policy. Nevertheless, the document of strategic plan is translated from the vision and mission of elected President and Vice President after 1998. Furthermore, the strategic plan, called Rencana Pembangungan Jangka Menengah ( RPJMD), is systemized for five years. In 2004, the Parliament passed a regulation for the strategic plan named Law No. 25 of 2004 on National Development Planning System. Three years later, in 2007, it was enacted by Law No. 17 of 2007 on Rencana Pembangunan Jangka Panjang Nasional (RPJPN) National Long Term Development Planning - of 2005-2025. Therefore, it can be concluded that since 2007 Indonesia, after the end of Soeharto's authoritarian government, has long term strategic planning document for the next 20 years.

The interesting question regards the compliance of government with this strategic plan. In other words, how will the strategic plan be implemented? The question is closely related to the government capability in implementing the plan. It is in accordance with the purpose of this paper which is to observe the extent to which the strategic management principles will be implemented. The strategic management principles concern both the existence of future projection ability (Minzberg, 1999; Bovaird and Loffer, 2003) and the presence of various organization capacities to coordinate the conduct the plan (Salaman and Asch, 2003; Osborne and Brown, 2005).

However, the existing strategic plan implementation, either RPJMD or RPJP, was not as smooth as would bee expected. In 2009, the World Bank revealled the weaknesses in the mechanisms and frameworks of Government in dealing with coordinating the formulation and implementation of policies and programs across different branches, at both the central and local level. (World Bank, 2009, p.1). According to the World Bank both the decision-making processes underlying the formulation of policies and the programs delineation of roles and responsibilities needed for 
implementation of policies are often unclear. For instance, uncertainty about economic policies and regulations cited as one of the weakest aspects of Indonesia's investment climate, and it appears to stem primarily from a lack of coordination across different ministries at the national level and between the national and sub-national governments. Weaknesses in service delivery are also attributable to a confusion of roles and responsibilities between the central line ministries and local governments. The report acknowledged that is was to be expected that different parts of government may have invited different perspectives and priorities showed it clearly stated that Indonesia appears to lack clear and effective mechanisms for reconciling these differences.

In 2011 Indonesian government published a strategic plan called The Masterplan for Acceleration and Expansion of Indonesian Economic Development (MP3EI). This Masterplan was aimed at accelerating the achievement of long term development targets set in the RPJP, particularly for the development of infrastructure and industries. Secondly, the MP3EI tried to accelerate the participation of private foreign parties in the development of the infrastructure that is not described in RPJMN and RPJP strategic plan document. The document seems to be overlapping with other strategic plan document. Which raises the question of continuity?

Meanwhile, the World Bank's report indicates that the weaknesses are not only on the planning level, but also on the technical level of implementation. Furthermore it states that the decision making process is not well-understood between the levels of government with. each of government level having a different perspective on issues, leading to conflict among departments. Based on this problem, this paper will address how the strategic plan was designed and how has it been being implemented by Indonesian government since the reformation era.

\section{Theoretical Framework}

The introduction of the strategic management approach into the study of government or public administration began in 1980s in line with the development of the public management approach in the study of public administration. In 1990s, a New Public Management (NPM ) was introduced which was a renewal of public management by applying private organization systems to governmental organizations (Bovair, 2003). The term "core competence" (Prahalad and Hamel, 1994), for instance, was used for mapping the position of a state in the middle of strict competition within the international world. The current strategic management approach, which was transferred from the private sector to the public sector, experienced some adjustments in accordance with the characteristics and character of the public sector. The term Public Sector refers to government activity and its consequences (Lane, 1995, p. 15). Gvernment activity is more related to political activities closely related to allocating limited resources fairly to the public (Easton, 1965). The only way to allocate these resources is through long-term plans drawn up by the government.

Planning theory application in the public sector in accordance with Barone's theorem (Lane, 1995, p. 167) argues that there are two fundamental allocation mechanisms, the budget of the planning ministry and the private sector market, fulfilling the standard conditions for efficiency in resource allocation on the consumer side and the production side.

One approach employed is known as Design School offering a strategic model to reach a comparative suitability between internal capability and external possibility. The popular term used often "economic strategy" is regarded as the compatibility of the qualification with opportunities for the company position (Christensen, et al, in the Harvard Policy textbook, 1982: 164). Therefore, the motto of Design School is "suitability determination" or compatibility between the organizational qualification and the external opportunity.

The design school assessment derivation is sourced from two influential books, one by Philip Selznick' a social scientist of University of Berkeley California, entitled "Leadership in Administration" (1957) and the other by Alfred D. Chandlers, a social scientist from Massachusett Institute of Technology entitled "Strategy and Structure" (1962). Selznick introduced the idea of "specific competency' in an organization concerning its internal situation and external expectation and the key word "implementation" referring to social organization structure. policy making.

This approach follows Montanari's idea where. the government regulation was established to reach strategic positioning zone. Montanari and Bracker (1986:432) said that political cycles affect the strategic management process for five years, which is divided into four terms or phases of time. In the early days, the intensity of strategic planning is quite high, with secondary effects of primary high and low impact. Formulating a strategic plan does not significantly affect the activities of organizations operating in the short term. Planning will affect the activities of the organization at the end of the semester, when the period or term plan will be terminated and evaluated. Therefore, the impact of its implementation will be high primary and secondary curves as we see at Figure 1. 
Another approach offered by the public management school is that of Hatten, (1982), one of the few strategic management theorists to attempted to apply private sector strategic management concepts to the not-for-profit situation. Schendel and Hofer (1979) once said that, there was evidence that some of these organizations have no strategy at all. Newman and Wallender (1978) characterize not-for-profit organizations as poorly managed over the long term, with few or no long-range goal structures and having constraining characteristics different from profit-making organizations. Meanwhile, Nutt (1984) and Nurmandi and Poernomo (2011) indicate that the diverse and sometimes conflicting assumptions that are made about goals in the not-for-profit organization make it essential to reflect on the organizational purpose prior to identifying and selecting strategic options. The absence of a goal structure and contextual analysis of the environment may then account for the continual cries of bureaucratic mismanagement in the not-for-profit organization spreading throughout the country.

The paradigm offered by public management which includes a strategic plan from many results of policy studies research and implementation analysis as well as organizational theory implies that the paradigm is systematically ambiguous and inherently unreliable in the governance of public organizations (March and Olsen, 1976; Pressman and Wildavky, 1984; Hogqood and Peters, 1985).

In accordance with the title in this research, sustainability, then the writer will focus on the continuity of plans that have been arranged. Is the organization consistent with the plans that have been prepared? Does the leader use the plans to arrange the programs? Is there regular monitoring of the implementation plan? Does the practitioner obey the strategic plan? Salman and Ash have mentioned the organization;s ability to achieve the purposes that have been decided as its organizational capability. Moreover, Salman and Ash define capability as the degree to which the organization is structured to ensure the achievement of the goals: the extent to which the culture is appropriate for their achievement, the degree to which there are the right sort of people with the right atttitudes and skills and attributes in the right numbers, motivated, rewarded, equipped, trained and managed to do the right sorts of things in the right sorts of ways (Salaman and Ash, 2003, p. 27).

Although Salman and Ash have set the achievement indicators of a strategic plan, many social scientists are not satisfied with its implementation. Therefore in order to map the problems better towards the implementation problems of the design model's plan, the writer has tried to investigate the factors that affect the implementation of strategic planning. Denning (2005) stated that strategy development - strategy and implementation -- must be anchored in leadership and the most effective way to communicate with people that they try to lead is very often through story. Antonio Grilio, et al (2010) and Nicolis (2007) suggest development strategy analysis is distinguished by four factors, namely:

Circular and network causality -- as opposed to simple systems, where causes and effects can be separated, a system is certainly complex if an effect feeds back to its cause.

Emergence - within a system composed of many units (agents) the global properties and behaviour cannot be reduced to the sum of the units comprising the system. Emergence has to do with the certainty and maintenance of hierarchical structures in which the disorder and randomness that inevitably exist at the local are controlled.

Self-organization --- when complex adaptive systems reach a state of self -organized criticality, then the system changes which occur are likely to follow a power law. This stems from the degree of hierarchical interconnection of agents within the system, which leads to non-linear behaviour.

Fitness - all value-creating socio-economic transformations and transactions produce outputs that are fit for human purposes. It is not possible to say which is the optimum fitness in the environment landscape, but it is possible to compare the degree of the fitness between the inner characteristics of the system and the landscape.

\section{Analysis Result}

Since the Soesilo-Boediono' United Indonesia Cabinet II was inaugurated, it has arranged the document of RPJMD for the implementation of Law No. 25 of 2004 mandate on a National Development Planning System. Furthermore, in 2007, it enacted Law No. 17 of 2007 on Rencana Pembangunan Jangka Panjang (RPJPN) - Long Term Development Plan of 2005-2025. The RPJPN became also the reference in the arrangement of Regional RPJP and became the guide for President and Vice President candidates in drafting the five-yearly Rencana Pembangunan Jangka Menengah (RPJM) - Middle Term Development Plan - and the Rencana Kerja Pemerintah (RKP) Government Work Plan. The success of the national development plan in actualizing the vision of Indonesia independent, innovative, fair and prosperous - the independent, advanced, just and prosperous Indonesia - needed to be supported by (1) the strong and democratic commitment of national leadership; (2) the consistency of government policy; (3) the alignment to people; and (4) the active participation of the community and business worlds. 
The Annual plan (RKP) is arranged based on the response of the running-condition led by "the gang of four" and the legislative's budget division. Strategic policy process formulation since 1998 has been driven by the "Gang of Four" in executive side and Budget Body in Legislative side. The "Gang of four" leads macroeconomic policies and comprises:

1). The Ministry of Finance (MF),

2). The Ministry of Planning (MP)

3). The Coordinator Ministry of Economic Affairs (CMEA)

4). The Ministry of Home Affairs (MHA).

In the beginning of RKP setting, the National Development Planning Board formulates a policy draft suitable for the mission, which is also suitable for RPJMN and RPJP. The next mechanism is the discussion in Musrenbang Nasional attended by all ministers, state bodies, governors, social and religion leaders, and pers.

In the forum, the" gang of four" explained the most recent situation and condition of the national economy but they did not have enough time to discuss about the achievement of the goal of the strategic plan. The National Development Planning Board conducted evaluation on the achievement of RPJMN (Medium Term Plan) in the form of annual evaluation which then became the guideline for setting the RKP (annual plan), as it has been in the form of an example of RKP (annual plan) achievement. The method of strategic plan using the design school approach seems to give colors to the strategic plan structure. The establishment of the target for the strategic plan was difficult to attain because of the changes of assumption and the condition of environment.

\section{Legislative's Budget Division}

The Budget Division is a permanent division ordered by Legislative. Its members are taken proportionally from all factions. In carrying out running its function, this division has a secretariat and a team of experts. The main duty of this division is discussing state budget expenditure (APBN). The various forums that can be used by this division among other are: working meeting with the Executive Body, meeting for listening to opinions, or the meeting for listening to public opinion (but conducted infrequently).

In fact, this forum is very important because it will be a communication space for and between the representatives and the entity or a group of people that they represent. The Budget Division can make a working committee, that is generally divided into three: a working committee for macro assumptions, for receiving and deficit/expenditure; a working committee for the expenditure of central Ministries/Bodies, and a working committee for regional expenditure. The working committee has a duty to give recommendations to the meeting division about matters considered important to exist on the Legislative agenda. In fulfilling its duties, the Budget Division can set the draft of budget that is suitable for the need, and then will be delivered to Legislative's Neighborhood Affairs Division.

\subsection{The Preface Talking between Executive and Legislative}

The year of State Budget Expenditure goes from January 1st to December 31st, but the arrangement process begins in the previous year. According to article 14 line 1 law no. 17 of 2003 on state monetary matters, ministers/the head of bodies who are going to use the funds/ or who use the things should make arrangemens for a working plan and the budget for the ministries/bodies for the next year. The working plan must be set so as to be suitable for the performance that is going to be achieved. Then, it should be submitted together with the estimation of the expenditure in the next year or for the period after the yearly budget that is being arranged. The Figure 5 tries to map the structure of relationship among the actors in setting the annual plan and the budget.

Route 1: gang of four is a very influential circle in setting both the annual plan (RKP) and the budget. In the route 1, the mechanism of the plan is based more on a technocratic approach than politics and the assumptions of economic and monetary matters are involved more in the setting of the annual plan. The macroeconomic policies of SBY-Boediono administration is more frequently trying to give subsidies for the oil fuel and to increase civil servant wages annually.

Route 2 describes the structure of relationship that is close and interdependent. The Budgeting division of the legislative is very a powerful. The Legislators consider that they have the right to submit a suggestions that can cause the changing of the state budget expenditure, and the right itself has been regulated in the constitution. The authority of Indonesian legislative's budget division for the excess budget of national budget expenditure is much more powerful. This circumstance is revealed in the bribery case of the acceleration of funds for regional infrastructure development. 
Route 3 describes the relationship structure among the political parties and legislative's budget division. This relationship is a mutual symbiosis. The political parties encourage their representatives who take responsibility for being members of the budget expenditure division to fight for the parties interest, particularly for the interests of the area from which they had been elected.

Route 4 shows the relationship structure that is indirect, but interdependent. The gang of four needs a legitimation from the political parties, especially the political parties whose who have ministers in the cabinet.

Route 5 describes the weak structureal relationship between the citizen and the gang of four. This is because there is no regulation that forces the ministry to disseminate the plan draft to citizens.

Route 6 gives a description of the relationship structure between Legislative Budget Division and the citizens. Although this should be a strong relationship, in fact it is weak. In this case, because the Legislative Budget Division has never disseminated the draft plan to the public.

Route 7 depicts the weak relationship among the citizen, media, and NGOs. The planning structure described above shows the complexity of the planning process involving many organizations in decision making. Until 2011, the number of autonomous areas in Indonesia was 618, consisting of 33 provinces, 497 Regencies, and 98 cities. Based on Law No. 32/2004, regency responsibilities have two areas of obligatory responsibilities and optional areas of responsibilities). This approach is uniform for all autonomous areas in Indonesia except Papua, Aceh, and Jogyakarta. The Home Affairs Ministry---in accordance with the law--- conducted the evaluation for 33 strategic plan documents and the plan of revenues and expenditures of all provinces. Meanwhile, each of the Provincial Development Planning Boards should review the strategic plan as well as its below district and city revenue and expenditure plans. The question is, can such a mechanism work well?

From the perspective of complex adaptive systems, in strategy development, all planning units interact at in the National Musrenbang mechanism (Annual National Meeting) and hoeld the assimilation of information, resulting in the evolutionary behavior. Planner's behaviour at the regional level is indicated by making an annual plan in the form of a Local Government Work Plan (RKPD) derived from the General Policy Direction in accordance with the priorities and sometimes not in accordance with RPJMD that have been developed.

Meanwhile, at the level of the Government, the Musrenbang agenda is more of a ceremonial forum and does not touch the issue of budget deficit to finance the strategic plan.

\subsection{Obsctacles of Design School}

The main weakness of the design school planning method as used in the RPJMN setting, is handling problems such as global environmental issues not anticipated in the 2009 planning document. The second challenge in carrying out the RPJMN is the difficulties in coordination of the ministries with the state bodies and also the local government around basic assumptions, for instance, the target to decrease poverty and to increase economic growth.

In its study on the implementation of RPJMN in 2009 in various development agendas the World Bank used indicators to assess the implementation of Indonesia's strategic plan, including :

1). Policy and regulatory quality

2). Government effectiveness: coordination, capacity and accountability;

3). Control of corruption

4). Rule of law

The Study assessed beyond the development agenda formulated in RPJPN and RPJMN concerning economic growth enhancement, equitable development, sustainable development and natural disaster management. The proroty policies of the first agenda were, infrastructure development and policy improvement and the results of the study showed policy uncertainty related to land acquisition for infrastructure. In 2005, the Government established the National Committee on Policy for Accelerating Infrastructure Provision (KKPPI) as an inter-ministerial committee headed by the Coordinating Minister of the Economy. In February 2006, the policy was announced with a Policy Package outlining more than 150 reforms. Moreover, in July 2007, the government announced a further Presidential Instruction 6/2007 on the integrated economy policy and Presidential Instruction 5/2008 on regulatory and institutional reform. However, the policy packages did not display success in spurring the development of infrastructure. Infrastruture investment rose from a low of 2 percent of GDP in 2000 to just 3 percent of GDP in 2005 mainly because the development of infrastructure faced significant barriers, especially from local government. According to the World Bank Study (2009) it is the weaknesses in the mechanism and frameworks that Indonesia has 
in place for coordinating the formulation and implementation of policies and program within and across the diffrent branches of government, at both the central and local level that have hampered the government's effectiveness in the delineation of roles and responsibilities. One major weakness that is felt so far in the system of national and regional development planning in Indonesia is the lack of alignment, either cross-sectoral, inter-provincial and national, inter-adjacent provinces and between districts/cities (Andi Erwin, 2010).

In an opinion Hearing Meeting between the Head of BAPPENAS and the members of Regional Councils (DPD) on 20 June 2011 about MP3EI it was stated that:

In response these things, Sofia Maipauw (Regional Councils of Indonesian republic from the province of West Papua) highlights the frequent discrepancy between what the government planned and its implementation. This can be seen from the unrealized of Musrenbang (Development Planning Development)'s proposals from village to provincial level when the policy set forth in APBD (Regional Expenditure Revenue Budget). "The term of the Papuans, different excercise-different play. This means that when we exercise the choir with tone in this way, when singing the song the pitch changed much from those have already studied. It is same with the development approach that simply changing the name but its substance is the same," said Sofia.

Answering these doubts, Armida admitted there were still weaknesses in the process of Musrenbang to Musrenbangnas. Therefore, besides evaluating the mechanism of Musrenbang, the government also considers the inputs from the region. "As in the Master Plan, the government together with BUMN (State-Owned Enterprises) and privates, must realize the acceleration and expansion of economic development," close Bappenas Head.

Pessimism among members of the Regional Councils is reflected among the senators who are against any government' strategic plan. One important point to be criticized is the mechanism of the National Development Meeting (Musrenbang) which is routinely held every year. The content of this forum is a series of speeches from president and ministers concerned and there was no evaluation of what has been achieved in the current year.

\subsection{Joint Circular Letter Culture}

One method used by the ministry to solve the problem of inter-ministerial lack of coordination was to issue a joint decision or joint circular letter. In one of the collective decision letters to deal with the uncoordinated planning between the Government and Local Government, in 2010, four ministries issued a Joint Regulation of the Home Affairs Minister, Minister for National Development Planning / Head of National Development Planning Agency and the Minister of Finance No: 28 of 2010, No: 0199 / M PPN/04/2010 and No: PMK 95/PMK 07/2010 About Alignment Regional Medium Term Development Plan (RPJMD) with the National Medium Term Development Plan (RPJMN) 2010-2014.

The issuance of this regulation indicates the problem with coordination of this plan could seem funny and bizarre in the planning and suggests that the coordination at the central government was facing serious problems. Should the Ministry of the Home Affairs and the Ministry of Finance conduct direct filtration programs and activities that are not suitable for RPJMN? But the pattern of this evaluation was not effective.

The same pattern also applied to the special budget allocations to local governments. In Specific Purpose Grant Allocation for Local Government (Dana Alokasi Khusus), the Central Government through the National Development Planning Board (Bappenas) with the Ministry of Finance and the Ministry of Home Affairs, also issued a Joint Circular Letter by the Minister of National Development Planning Board (Bappenas), the Minister of Finance and Minister of Home Affairs, Number 0239/M.PPN/11/2008; SE 1722/MK.07/2008; 900/3556/SJ,date 21 November 2008, on the Technical Implementation Guidelines for the Implementation of Monitoring and Evaluation of Utilization of the Specific Purpose Grants. A joint Circular Letter is necessary to improve the effectiveness and efficiency in the implementation of monitoring and evaluation of the Specific Purpose Grants. The model of this shared decree was carried out also in other policies.

\subsection{Coordination}

Coordination becomes a word that is usually uttered by the President, in fact, however, coordination is a difficult activity to bring about. The evaluation by the World Bank above shows that coordination faces quite difficult problems both at the ministries level, and between the ministries and the local government by referring to O'Toole and Monjoy's opinion that the relationship pattern among ministries is a much more competitive relationship. Each

ministry or agency has its own targets which are different to each other and difficult to combine into a collective target. The competition between ministries appears from various cases that have arisen in recent years, which are described as follows: 
Case 1.

The massacre of Mesuji area farmers in Lampung and South Sumatra caused by poor coordination between ministries. The National Commission for Human Rights said that there were at least three ministries in charge. As is known, most Mesuji residents are migrants. The protracted conflict that led to the massacre of Mesuji farmers was due to the expansion of oil palm permission provided by the Ministry of Forestry and the Ministry of Agriculture to SWA Limited.

Case 2.

The Head of State is also aware of a number of issues in addressing this problem. Some of them are issues of coordination and synergy between ministries, between central and local, and also between the government, business and the general public. According to SBY, if there were problems, they could return to the vision and basic policies related to the climate change and development goals (30/09/2011).

Case 3.

It was the weak, fragmented nature of government, characterized by power struggles, anarchy, conflict and contradictory laws that blurred the lines between legality and illegality and therefore made it easier for illegal logging, supported by collusive corruption, to flourish. Periods of transition from autocracy to democracy are particularly vulnerable to burgeoning collusive corruption, because during transitions, institutions essential for fully functioning democracies are still underdeveloped, leading to a governance vacuum (J. SMITH, et al, 2003)

From the report of the Ministry of National Development Planning on the 10 priorities of RPJMN 2010-2014 (see appendix), we can summarise the constraints of each priority, namely:

1). Priority of bureaucratic reform and governance: accountability, corruption and regulation

2). Education priority: educational facilities disparities between regions

3). Health priorities: health facilities and human resources

4). Priorities of poverty: corruption and planning capacity

5). Food security priorities: climate, accessibility to a production facility and high demand

6). Priority of infrastructure: the limitations of the development fund

7). INVESTMENT AND BUSINESS CLIMATE Priority: variations of investment and high-cost economy procedures.

8). Priority of Energy: shortage of funds and delayed project implementation

9). Priority of environment and natural disasters: coordination among government units.

10). Border and disadvantaged areas development priorities: lack of Infrastructure and unclear responsibility.

\subsection{Managing Complexity and and Shared Responsibility}

Economic policy under the conditions of globalization means more than administration and distribution of resources, This latter perception is predominant still in all parts of Indonesia's economic system, but particularly in the Public Sector as the Case Study from Yogyakarta as well as the review on National Policy as this article illustrates. Making policy goes beyond administrative and distributive routines and, requires creative mindsets with a capacity to understand complexity in the respective policy sector. Thus making economic policy needs economic expertise and strategic management capacities at all levels of governance (national, regional, local), in conjunction with an alignment of inner- and intergovernmental procedures. In particular professional standards and a coordination of analysis, policy recommendations and the transfer of policy into indicators for measuring success and evaluating results are a conditio sine qua non for successful economic policy.

The necessary multi dimensional improvement of capacities in Indonesia must start with the practice of overall management (or "leadership"). It needs to follow not only ethical thinking, but also legal and professional standards. It must bid farewell to forms of traditional authority without professional foundation.

Successful economic policy based on principles of Good Governance will be judged on its output, a visible better life for all and use of related qualified indicators. Sub-national Governance plays an important role in concretizing the ambitious targets of national policy by transferring abstract goals into the concrete regional political and economic situation. The benefit of a successful decentralization policy for Indonesia may become apparent particularly in this 
policy sector, and successful economic policy based on professional Strategic Management could thus contribute to a stronger democratic culture in the country and within its institutions.

The complexity of implementing a strategic plan that had been developed can be described in the following figure Figure 5. Presidential leadership is an important factor in encouraging the achievement of a predetermined plan. With a clear vision, then he will monitor the performance of the ministers in a unity of command work. With this clear command accordingly the inter-ministerial coordination will be better. Meanwhile, the ministry's performance is affected by the capacity of bureaucrats, especially the directors-general and directors of the officials implementing the policy. Directly, the ability of the implementor of this policy affects the sustainability of the existing strategic plan. From the aspect of local government---with the State Revenue Budget Spending allocation of $25 \%$ for the general allocation fund, the capacity of local governments significantly influences the sustainability of the strategic plan.

\subsubsection{Oli Price}

One of the strategic policies that will get more popularity and does not want to face the public turbulence is the energy subsidy policy. In the Revised Budget 2011 this was increased by 31 trillion rupiah to 160 trillion rupiah, exceeding the initial plan of 130 trillion rupiah. Until 2013, the government of SBY-Boediono has been and will be spending public money to subsidize misdirected fuel at more than 700 trillion million (Anggito Abimanyu, 2011).

The policy to provide fuel subsidies is more about trying to maintain popularity than the strategic achievement of a predetermined plan. Such huge funds could be used to build infrastructure. But this kind of rational analysis cannot answer why the government of SBY-Boediono remained determined to provide fuel subsidies. Following Denning's view, the president's leadership is more influential than the sustainability of development strategy of the plan itself.

\subsubsection{MP3EI Master Plan: Another Strategic Plan}

Due to a large state budget shortfall for development as a direct result of the populist policies in 2010 the government launched a new planning document named The Masterplan for Acceleration and Expansion of Indonesian Economic Development (MP3EI) in Figure 6 and Figure 7. This directive was aimed at implementing the 2005-2025 Long-term National Development Plan, which was stated in the Law No.17 Year 2007, the vision of the acceleration and expansion of Indonesia's economic development to create a self-sufficient, advanced, just, and prosperous Indonesia. By utilizing the Masterplan for Acceleration and Expansion of Indonesia's Economic Development (MP3EI), Indonesia aims to earn its place as one of the world's developed country by 2025 with expected per capita income of USD 14,250-USD 15,500 with total GDP of USD 4.0-4.5 Trillion. To achieve the above objectives, real economic growth of 6.4-7.5 percent is expected for the period of 2011-2014. This economic growth is expected to coincide with the decrease in the rate of inflation from 6.5 percent in 2011-2014 to 3.0 percent in 2025. The combined growth and inflation rates reflect the characteristics of a developed country.

In its explanation, MP3EI claims to be an economic field action document. From a substantive aspect, this document is more of a strategic plan that follows the flow of positioning, which aims to place the place of Indonesia in the middle-income countries. Further it explains:

"MP3EI is a working document and as such that will be updated and refined progressively. It contains the main direction of development for specific economic activities, including infrastructure needs and recommendations for change/revision of regulations as well to initiate the need of new regulations to push for acceleration and expansion of investment. MP3EI is an integral part of the national development planning system. MP3EI is not meant for substituting the existing Long Term Development Plan 2005 - 2025 (Law No. 17 Year 2007) and the Medium-Term Development Plan 2004 - 2009 (Presidential Decree No. 7 Year 2009). MP3EI is formulated in consideration of the National Action Plan for Greenhouse Gas (Rencana Aksi Nasional Gas Rumah Kaca - RAN GRK) as a national commitment which recognizes the global climate change".

MP3EI does not yet adequately describe how the expansion of development can be realised (M. Hidatullah, 2011). Furthermore Hidayatullah (2011) critized MP3EI for three anomalies. Firstly, as many as 74 percent of the indicative value of investments during 2011 - 2014 will be located in the Economic Corridors of Sumatera, Java, and Kalimantan, while the three other corridors (Sulawesi, Bali - Nusa Tenggara, and Papua - Maluku Islands) only account for 26 percent. In contrast, infrastructure investments in the three economic corridors are only indicated to reach Rp 275 trillion, while the total indication of overall investments in all the corridors reaches Rp 1,700 trillion.

The second anomaly is found in the planned development of Sulawesi Economic Corridor. As written in the MP3EI [documents], the Sulawesi Economic Corridor has a development theme of Production and Processing Centre of National Agricultural, Plantation, Fishery, Oil and Gas, and Mining Products. However, of the Rp 69 trillion 
indicated for infrastructure investment, Rp 34 trillion is for the development of telecommunications infrastructure (49 percent), which is less relevant to the theme of the corridor. The construction of infrastructure that can support the agricultural sector has instead received a small budget, such as water utility infrastructure which only gets a 'quota' $\mathrm{Rp} 0.1$ trillion ( 0.14 percent). In addition, construction of roads and ports, which is the core infrastructure in creating connectivity, only gets $\mathrm{Rp} 5$ trillion (7.24 percent) and $\mathrm{Rp} 6$ trillion (8.6 percent), respectively. A third anomaly occurs in the development of Bali - Nusa Tenggara (NT) Economic Corridor. The development theme of the Bali - NT Corridor is the Tourism Gateway and National Food Support (Hidayatullah, 2011).

\section{Conclusion}

Based on the analysis of the implementation MP3EI and RPJMN, it could be founded that the main obstacles are the President's vision and leadership, lack of good policies, lack of coordination of the Ministries the ability of the bureaucrats and corruption. Each of these factors contributed to a substantial document on the implementation of the two strategic plans. The President also has to respond to environmental situations that often change, in forms of emergent plan is more often observed by the community.

\section{References}

Behrens, Cristhop. (2010). We could meet with Modernity. Public Administration Reform and Good Governance in Yogyakarta. Yogyakarta 2010.

Behrens, Cristhop. (2012). Modern Governance For Indonesia. Jakarta 2012.

Bovaird, Tony, \& Elke Loffer (ed). (2003). Public Management and Governance. London: Routledge.

Christensen, C. Roland. (1982). Strategy Design, PUBLISHER:Division of Research. Harvard Business School (Boston, Mass.). SERIES TITLE: YEAR: 1981. PUBTYPE: Book. VOLUME/EDITION: PAGES (INTRO/BODY).

Denning, Stephen. (2005). The Leader's Guide to Storytelling: Mastering the Art and Discipline. Wiley, New York.

Erwin, Andi. (2010). Pelaksanaan RPJMN (RPJMN Implementation). Thesis UI.

Grillo, Antonio, \& et al. (2010). Strategic Management of Public Administration: Applying Complex and Evolutionary Systems Theories. paper presented at European Public Administration Conference at Portugal, 11-12 November 2010.

Hatten, Mary Louise. (1982, April/June). Strategic management in not-for-profit organizations. Strategic Management Journal, 3(2), 89-104.

Hidayatullah. M. H. (2011). Anomalies of MP3EI, Bussiness Indonesia, October 11.

Hogwood, B. W., \& Peters, G. B. (1985). The Pathology of Public Policy. Oxford: Clarendon Press.

Lane, Jan-Erick. (1995). The Public Sector, Concept, Models and Approaches. Sage, London.

Laurence J. O’Toole, \& Robert S. Montjoy. (1984). Public Administration Review, 44(6), 491-503.

March. J. P., \& Olsen, J. P. (eds). (1976). Ambiguity and Choice in Organizations. Oslo: Universitetforlaget.

Mintzberg, Henry, \& et al. (1998). Strategy Safary. New York: The Free Press.

Montanari, Jonh R., \& Jeffrey S. Bracker. (1986). Strategic Plan in Public Sector Unit. Strategic Management Journal.

Newman, H. William, \& Harvey W. Wallender. (1978, January). Managing Non-Profit Enterprise. The Academy of Management Review, 3(1), 24.

Nurmandi, Achmad, \& Eko Poernomo. (2011). Making Strategic Plan Works in Local Government: A Case Study of Strategic Plan Implementation in Yogyakarta Special Province (YSP). International Review of Public Administration, 2(16)

Nutt, Paul C., \& Robert W. Backoff. (1992). Strategic Managementof Public and Third Sector Organizations: A Handbook for Leaders. San Francisco: Jossey-Bass.

Prahalad, C. K., \& Gary Hammel. (1984). Strategy as a field of study: Why search for a new paradigm? Strategic Management Journal, 15.

Pressman, J., \& An Wildassky, A. (1984). Implementation. Berkeley: University of California Press.

Salaman, Graeme, \&David Asch. (2003). Strategy and Capability. Balckwell Publishing. 
Schendel, D., \& Hofer, C. (ed.) (1979). Strategic management: A new view of business policy and planning. Boston: Little Brown.

Yacinta Esti. (2011). Perencanaan, Penyelenggaraan, Pengembangan Kebijakan: Sebuah Model untuk Sektor Pertanian dan Ketahanan Pangan. Yogyakarta 2011.

\section{Document}

Rencana Pembangunan Jangka Menengah Nasional, www.setneg.go.id

MP3EI, www.setneg.go.id.

Evaluasi RPJMN, www.bapenas.go.id

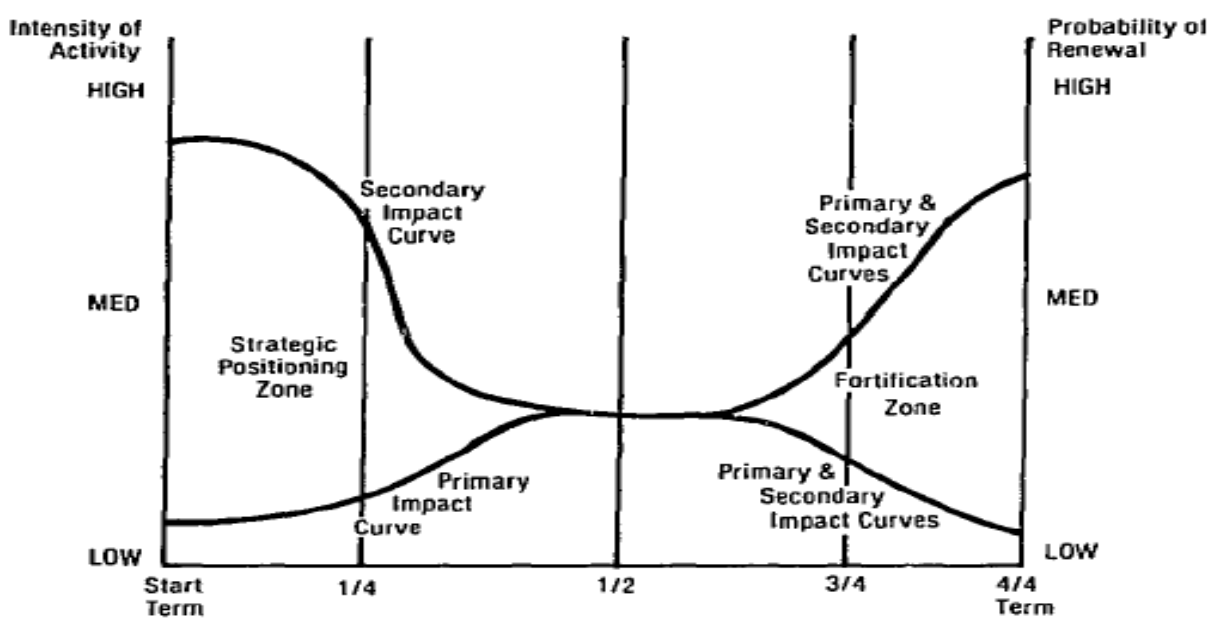

Figure 1. Political cycle work unit area

Sources: John R. Montanari and Jeffrey S Bracker, 1986.

\section{Strategic Plan Flow}

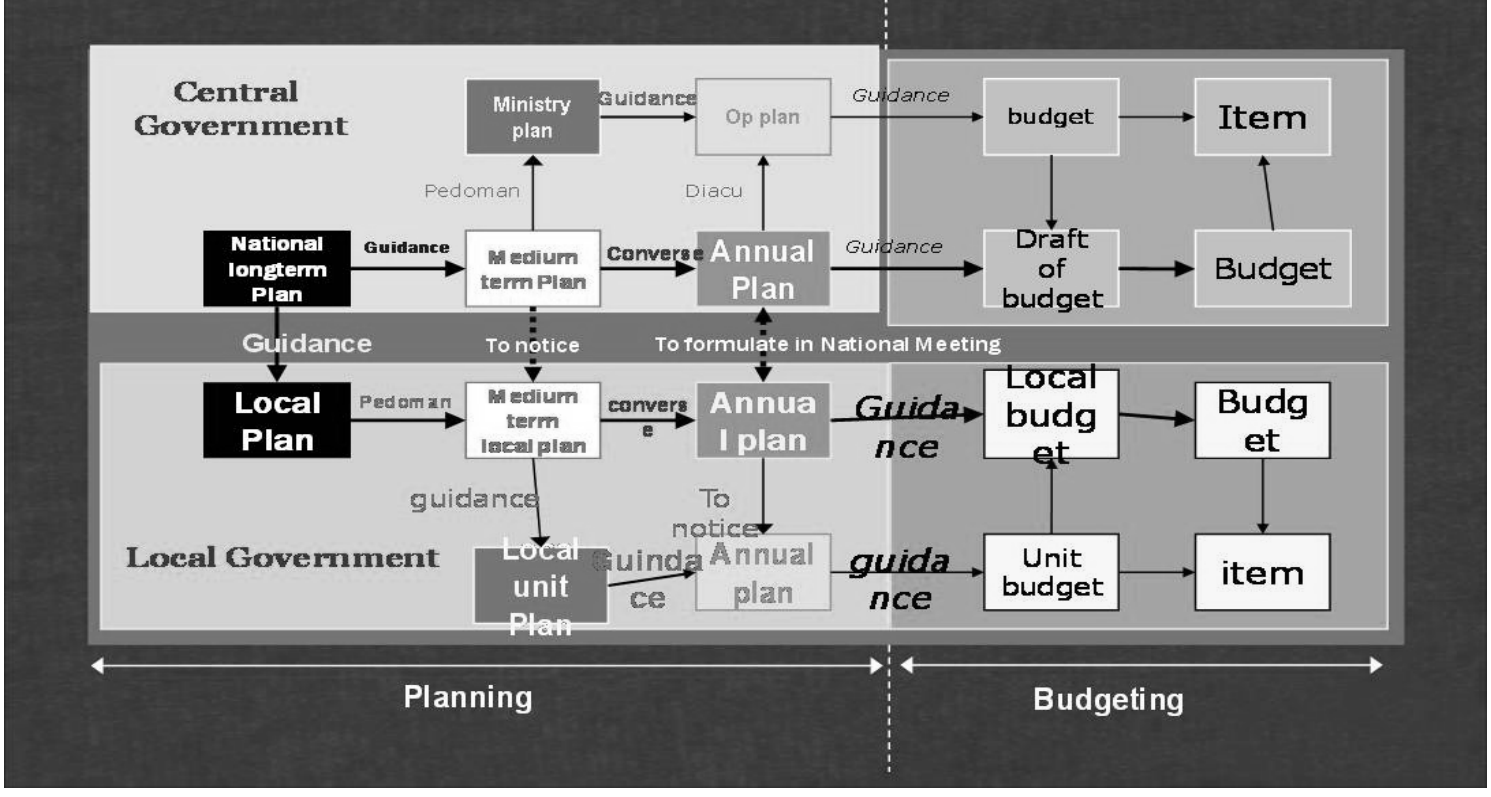

Figure 2. Structure of strategic plan 


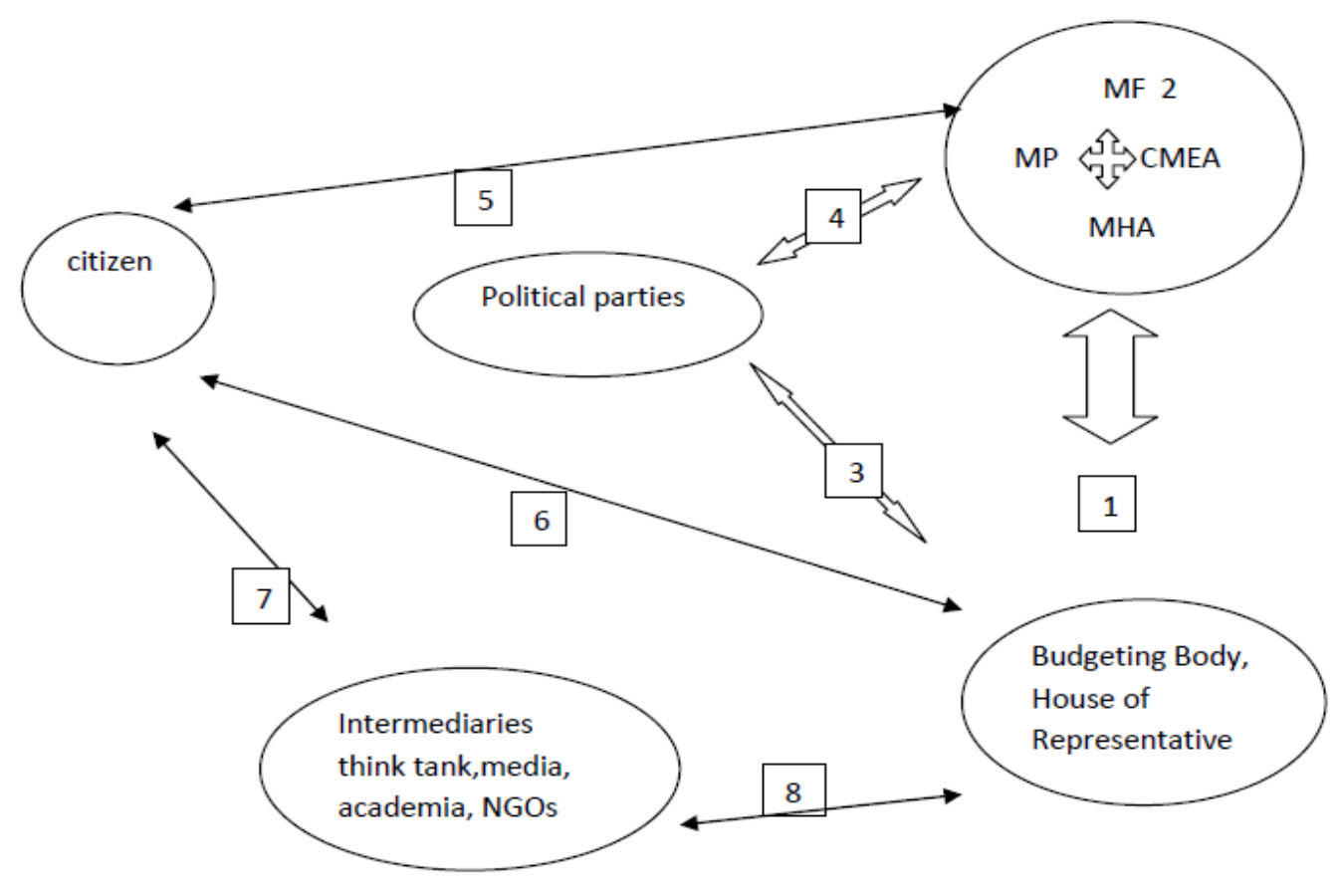

Figure 3. Principal actors

\section{Chart A: Why furthering Indonesia's gowemance transition matters for realizing Indonesia's development ag̣enda}

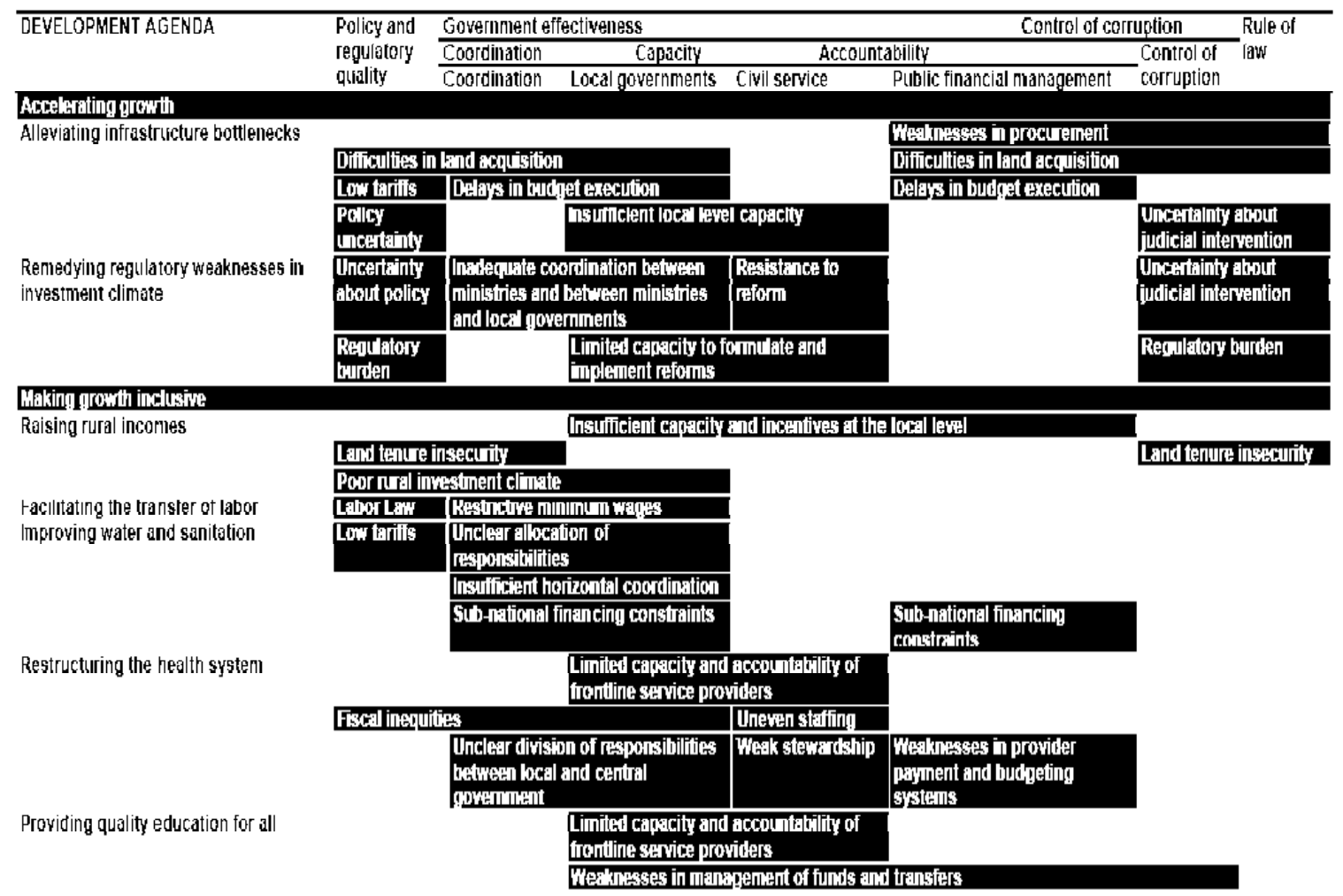

Figure 4. Weaknessess of strategic plan implementation 


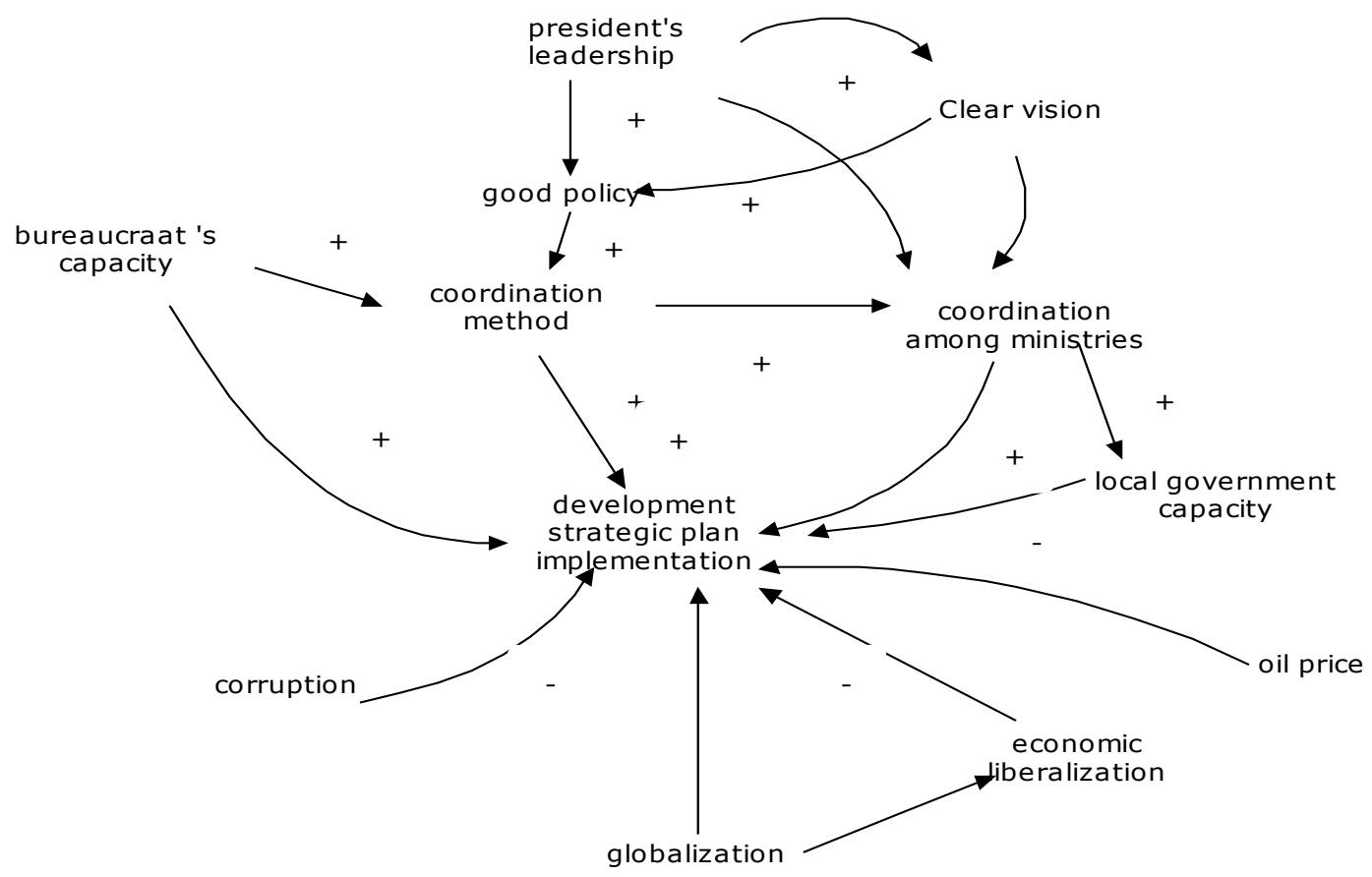

Figure 5. Causal relationship in RPJMN implementation

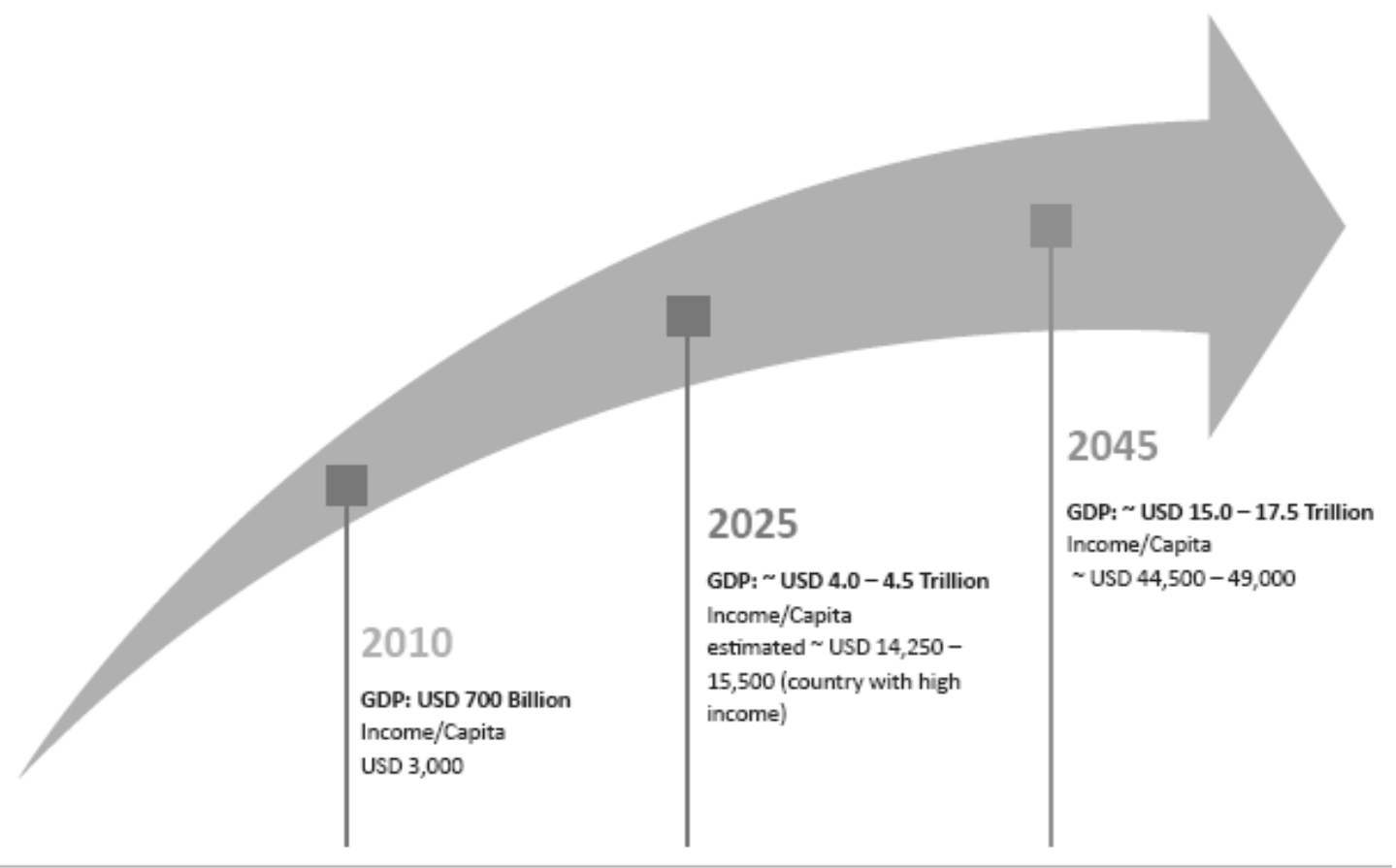

Figure 6. Plans for Indonesia's GDP 


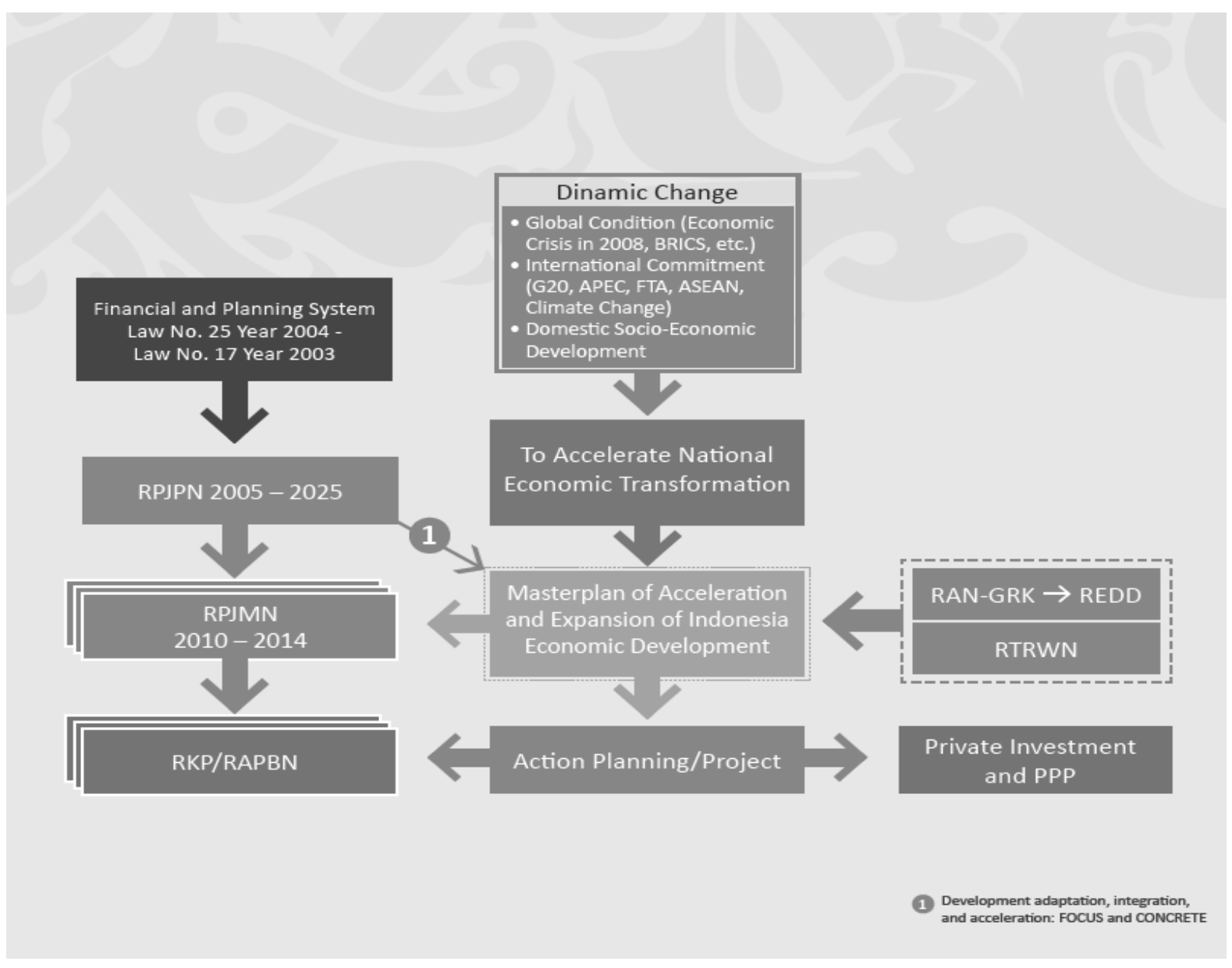

Figure 7. RPJMN and MP3EI 